\title{
Venture Capitalists, Monitoring and Advising
}

\author{
Roberta Dessí*
}

February 2, 2009

\section{Introduction}

Venture capitalists are widely regarded as financial intermediaries who provide not just financing, but also advice and monitoring. This view rests on solid empirical foundations: according to Gorman and Sahlman (1989), for example, lead venture investors visit each portfolio company an average of 19 times per year, and spend 100 hours in direct contact (on site or by phone) with the company. Venture capitalists play a very active role in negotiating with suppliers, helping to recruit and compensate key individuals, replacing founders with outside CEOs, providing strategic advice and access to consultants, investment bankers and lawyers (Gompers and Lerner (1999), Hellmann and Puri (2002), Lerner (1995), Kaplan and Strömberg (2003, 2004), Sahlman (1990)).

This chapter develops a unified theoretical framework to analyse the implications of venture capitalists' multiple roles as financiers, monitors and advisers. The model is used to address three main questions:

(i) what is the optimal allocation of cashflow rights and control rights between entrepreneurs and venture capitalists? Does this correspond to what is commonly observed in venture capital contracts?

(ii) what are the different implications of venture capitalists' roles as financiers, monitors and advisors?

(iii) in what way does the desirability of deterring potential collusion between entrepreneurs and venture capitalists, at the expense of other investors, shape the

*Toulouse School of Economics (IDEI and GREMAQ); dessi@cict.fr.

Correspondence should be addressed to: Roberta Dessi, IDEI, Toulouse School of Economics, Manufacture des Tabacs, Aile Jean-Jacques Laffont, 21 Allee de Brienne, 31000 Toulouse, France. 
structure of venture capital deals?

Each of these questions can obviously be investigated with a variety of approaches. The use of a single model to address all three questions has the advantage, beyond parsimony and simplicity, of exploring the connections between these different issues. For example, how does the allocation of control rights and cashflow rights affect incentives to monitor or advise relative to incentives to collude? This is one of the issues addressed below. On the other hand, the three questions set out above are very broad, and the answers generated here will be necessarily (very) incomplete: other chapters in this volume will provide plenty of additional insights.

The analysis developed below focuses on how financial contracts can be designed to achieve several objectives that are particularly important in the venture capital context. First, entrepreneurs need to be motivated to take efficient decisions for the venture: this may entail the provision of significant effort, and the willingness to sacrifice some personal benefits in order to increase the chances of commercial success of the company. For example, an entrepreneur might be tempted to pursue an investment project that he finds particularly interesting (e.g. it was "his idea"), or one that could give him considerable personal prestige, even though their expected profitability is much lower than for an alternative project. It may be possible to solve this potential moral hazard problem and provide appropriate incentives to the entrepreneur by giving him a sufficient monetary stake in the venture; however, this reduces the returns available for investors, and hence their willingness to contribute capital. When entrepreneurs are sufficiently capital-constrained, as is often the case for innovative start-ups, they may therefore turn to venture capitalists, who can alleviate the problem of entrepreneurial moral hazard through monitoring and intervention. This in turn leads to a second objective for venture capital contracts: they also need to induce venture capitalists to monitor efficiently.

As noted earlier, venture capitalists may play another valuable role, by providing advice on matters over which they have considerable knowledge and expertise. For example, venture capitalists will typically know the industry very well, and advice on strategic decisions, as well as helping to recruit key personnel. Thus a third objective of venture capital contracts may be to induce venture capitalists to provide advice efficiently. Finally, a crucial objective is to ensure that the venture is liquidated if its future prospects become sufficiently poor, or, on the contrary, that it is able to obtain the additional funding it needs to grow and invest when 
future prospects are sufficiently favourable ${ }^{1}$.

While this is by no means an exhaustive list of the objectives that need to be taken into account in the design of venture capital contracts, it does capture several of the key issues. Indeed, the need to elicit both entrepreneurial effort and $\mathrm{VC}$ advice has been the focus of numerous recent contributions to the theoretical literature on venture capital, as discussed in section 4, while the importance of inducing the efficient decision to continue or liquidate is central to the work of, for example, Admati and Pfleiderer (1994). The approach developed in this chapter extends this literature in two key respects. First, by studying all the issues outlined above within a single theoretical framework, and exploring the connections between them. Second, by identifying and exploring a crucial new factor in the design of venture capital contracts: the need to ensure that entrepreneurs and venture capitalists have no incentive to collude at the expense of other investors, whether these investors be the limited partners in the venture capital fund, nonventure investors involved at an early stage, or later-stage investors such as those acquiring shares in the company at an IPO.

The need for contracts to be collusion-proof rules out a number of otherwise feasible contracts. This makes it possible to obtain a number of implications, for example concerning the optimal allocation of cashflow rights and control rights, without imposing exogenous restrictions on the set of contracts that can be used. In this respect, the approach developed here differs from the one adopted in a number of contributions to the literature, which simply assume that contracts will be incomplete and that general control (ownership) rights will have to be allocated to the entrepreneur, the venture capitalist, or both (e.g. de Bettignies (2008)). In this chapter, on the other hand, the efficient allocation of control rights emerges endogenously through the analysis of optimal collusion-proof contracts. This makes it possible to obtain implications about the optimal allocation of specific control rights, which is consistent with observed practice in venture capital contracts, as discussed in detail in section 3.

The approach developed below sheds light on a number of features of venture capital financings, including:

(a) the widespread use of convertible securities, such as convertible debt or preferred stock, especially in the US;

(b) the allocation of control rights over the decision to continue or liquidate

\footnotetext{
${ }^{1}$ As will be clear from this list, the analysis developed here is particularly relevant to companies at the start-up and expansion stage, where monitoring by venture capitalists is most valuable.
} 
the project to venture capitalists, through the use of redemption rights, combined with negative covenants and staged financings;

(c) the certification role played by venture capitalists, whereby their decision to continue the project and exercise their securities' conversion option acts as a credible "good" signal to other investors (e.g. in an IPO).

The chapter is organized as follows. Section 2 introduces the model, based on Dessi (2005). The theoretical analysis developed in Dessi (2005) focused on the monitoring role of venture capitalists: this is studied in section 3. Advice (support) is examined in section 4, which establishes how the results of section 3 are modified if venture capitalists act purely as financiers and advisers - a case that has received considerable attention in the theoretical literature, but in different settings. The main innovation here is the analysis of how the possibility of collusion shapes optimal financial contracts between entrepreneurs and financiers/advisers. Section 5 concludes.

\section{The model}

The model, based on Dessi (2005), has three types of agent: entrepreneurs, venture capitalists (intermediaries) and investors. For simplicity, they are all assumed to be risk neutral and protected by limited liability. There are two periods. At the beginning of the first period, $t=0$, each entrepreneur has the opportunity to invest in a project, provided he can finance the required initial expenditure of value $C_{0}$. The interesting case, which will be the focus of our analysis, occurs when the entrepreneur does not have enough capital to undertake the project on his own. He can then seek finance from venture capitalists and/or other investors. In the presence of such external financing, there is a potential moral hazard problem at this stage, associated with the entrepreneur's choice of project. At the end of the first period, $t=1$, a "good" or a "bad" state is realised; the state determines the expected payoffs from continuing or liquidating the project. If the project is continued, it requires further financing of value $C_{1}$. It will then yield return $R>0$ at $t=2$ if it succeeds, and zero otherwise. If the project is liquidated at $t=1$, it generates a liquidation value $L$. There may then be a second moral hazard problem, associated with the decision to continue or liquidate the project. The model is described in greater detail below.

\section{Entrepreneurs}

At the beginning of the first period, each entrepreneur possesses some capital, $A_{f}<C_{0}$. He therefore needs to raise some external funds. At this point, there is 
substantial uncertainty about the returns that the project will generate. Some of the uncertainty is resolved at $t=1$, when the state, $\gamma$, is realised. The state may be "good" $\left(\gamma_{G}\right)$ or "bad" $\left(\gamma_{B}\right)$, where $\gamma_{G}>\gamma_{B}>0$. If the project is continued, it will either succeed, with probability $\gamma$, yielding verifiable returns $R$ at $t=2$, or fail, yielding returns equal to zero. The state $\gamma$ therefore represents the probability of success in the second period.

The entrepreneur's choice of project determines the probability of the good $\left(\gamma=\gamma_{G}\right)$ or bad $\left(\gamma=\gamma_{B}\right)$ state occurring. Specifically, the entrepreneur chooses between a "good" project, in which the good state occurs with probability $p_{H}$ , and a "bad" project, in which the good state occurs with a lower probability $p_{L}$, but the entrepreneur obtains a private benefit of value $B>0$ during the first period. In what follows I denote by $\Delta p=p_{H}-p_{L}>0$ the increase in the probability of the good state occurring associated with choosing the good project, and by $\Delta \gamma=\gamma_{G}-\gamma_{B}>0$ the difference in the probability of success between the good state and the bad state.

\section{Venture Capitalists (Intermediaries)}

Beyond providing capital, venture capitalists can perform one of two functions, advising and monitoring, or both. Advising (or "support") entails a variety of value-adding activities, such as helping to recruit and compensate key individuals, working with suppliers and customers, and helping to establish tactics and strategy. I shall formalise these by assuming that a venture capitalist can, by incurring a private cost $c_{a}>0$, increase the probability of the "good" state occurring by $q$, where $1-p_{H}>q>0$. Monitoring, on the other hand, enables the venture capitalist to limit the scope for opportunistic behaviour by the entrepreneur. I model this formally by assuming that, through monitoring, the venture capitalist can reduce the entrepreneur's private benefit from undertaking the bad project to $b$, where $B>b>0$. This alleviates the moral hazard problem associated with project choice. It can be interpreted as a restriction on the scope for opportunistic behaviour by the entrepreneur as follows: suppose there is a third project that the entrepreneur could choose, identical to the bad project described above except for a lower private benefit, of value $b$. Then by becoming informed, the venture capitalist can identify the bad project yielding the large private benefit $B$, and intervene to prevent the entrepreneur from undertaking this project. On the other hand, monitoring is not perfect and cannot eliminate moral hazard altogether: the entrepreneur can still choose the project with low success probability and private benefits $b$.

Monitoring (intervention) entails a private cost $c_{m}>0$ for the venture cap- 
italist. Both costs, the cost of monitoring and the cost of advising, cannot be contracted on. Appropriate financial incentives must therefore be provided to the venture capitalist to induce him to engage in either activity. These will need to take into account not only the need to compensate for the costs $c_{a}$ and $c_{m}$, but also any rents that venture capitalists may be able to earn because of the relative scarcity of financial intermediaries possessing both the skills and expertise of venture capitalists and substantial capital. In particular, I shall denote by $\alpha$ the gross expected rate of return on capital (per period), net of monitoring and advising costs, demanded by venture capitalists at $t=0$. The equilibrium value of $\alpha$ will be determined by the interaction between supply and demand for venture capital (see Dessi (2005) for details). Typically, this will exceed the rate of return demanded by other investors, for the reason just given. Entrepreneurs will therefore raise from venture capitalists only the minimum amount of capital consistent with obtaining their monitoring and/or advice. Any remaining need for external finance will be met by turning to other investors.

\section{Investors}

In contrast to venture capitalists, other investors are assumed to be small and/or to lack the necessary skills to become informed and intervene (monitor) or advise. For this reason, I will often refer to them as "uninformed investors" or "outside investors" in what follows. There are many of these uninformed investors in each period, so that it is always possible to raise finance from them by offering them their required gross expected rate of return, which is normalised to one. In the venture capital context, there are several possible interpretations of "uninformed investors". First, these investors could be the limited partners in a venture capital fund. Typically, these investors provide most of the fund's capital, but they are not closely involved with the portfolio companies and remain "uninformed" relative to the venture capitalist. A second possible interpretation of the outside investors is that they represent non-venture investors, who are sometimes brought on board by venture capitalists to participate in financing but without becoming closely involved with the companies that receive the funds. ${ }^{2} \mathrm{~A}$ third possible interpretation is that of new investors who acquire shares in the company when it is taken public, and who will be less informed at this stage than the venture capitalist who has been involved with the company from the start.

\section{The projects}

To make the analysis interesting, I shall make the following assumptions.

\footnotetext{
${ }^{2}$ The involvement of nonventure investors in the financing of venture-backed companies is documented for example by Gompers and Lerner (1999).
} 


$$
\gamma_{G} R-C_{1}>L
$$

Continuation is efficient at $t=1$ in the good state.

(A2) $\quad \gamma_{B} R-C_{1}<L$

Liquidation is efficient at $t=1$ in the bad state.

(A3) $\quad q\left[\gamma_{G}\left(R-C_{1}\right)-L\right]>c_{a}$

Advice is efficient.

(A4)

$$
p_{H}\left(\gamma_{G} R-C_{1}\right)+\left(1-p_{H}\right) L \geq C_{0}+c_{m}
$$

It is efficient to invest in the good project ex ante, even if it requires monitoring and there is no advice.

(A5) $B+\left(p_{L}+q\right)\left(\gamma_{G} R-C_{1}\right)+\left(1-p_{L}-q\right) L<C_{0}+c_{a}$

It is never efficient to invest in the bad project.

\section{Information}

I shall assume that the entrepreneur and the venture capitalist observe the realisation of $\gamma$ at $t=1$, but outside investors do not. This kind of informational advantage for "insiders" relative to "outsiders" (as in, for example, Admati and Pfleiderer (1994), Dessi (2005, 2007), Rajan (1992) and Schmidt (2003)) seems very plausible in the case of entrepreneurial start-up companies. It captures the idea that the venture capitalist has easier access to information about the firm's progress and prospects than outside investors, as well as the knowledge and expertise required to interpret the information correctly. Indeed, venture capitalists typically concentrate their investments in industries or sectors that they know and understand particularly well, having often worked in them (e.g. as entrepreneurs) prior to becoming venture capitalists. This is likely to be especially important for high-technology industries, where considerable technical expertise may be needed to evaluate progress in the early stages of a venture. 
Figure 1: timeline

$\begin{array}{lcc}t=0 & t=1 & t=2 \\ -----------------------------1 & \\ ------ & & \text { Project } \\ \text { Financial contracts } & \text { Realisation of } \gamma . & \text { returns } \\ \text { signed. } & \text { Decision to } & \text { realised. } \\ \text { Monitoring? } & \text { continue or } & \\ \text { Entrepreneur chooses } & \text { liquidate. } & \\ \text { good or bad project. } & & \\ \text { Advice? } & \end{array}$

\section{Monitoring}

This section studies the case where venture capitalists engage in monitoring but do not advise. Monitoring may entail a variety of interventions on the board of directors (e.g. to recruit and change management ${ }^{3}$, which in turn affects the firm's strategy and the entrepreneur's (founder's) ability to pursue his preferred project). I begin by assuming that collusion is never feasible. This assumption is then relaxed to study how venture capital contracts can be optimally designed when the possibility of collusion is allowed for. As we shall see, the resulting contracts ensure that collusion does not occur in equilibrium; moreover, the allocation of cashflow rights and control rights in these contracts is consistent with common practice in the venture capital industry.

\subsection{Collusion ruled out a priori}

If entrepreneurs possess sufficient own capital, they can obtain the external finance they require to undertake their project directly from uninformed investors, with no need for (costly) monitoring (see Dessi (2005) for details). Since this entails no role for venture capitalists, I shall focus instead on the case where entrepreneurs have insufficient own capital, and cannot finance their project without monitoring by a venture capitalist.

The venture capitalist's informational advantage relative to other investors means that there are two informed parties at $t=1$, the entrepreneur and the

\footnotetext{
${ }^{3}$ On this see Kaplan and Strömberg (2004).
} 
venture capitalist. Ex ante, contracts can be designed to ensure that information about the realised state $\gamma$ will be obtained from these informed parties at $t=1$, and that the information will be used to make the efficient choice between continuing and liquidating the project. In fact, when collusion is ruled out exogenously, this can be achieved at no additional cost relative to a situation in which the state $\gamma$ is publicly observable and contractable; in other words, the informational asymmetry between entrepreneur and venture capitalist on the one hand, and outside investors on the other hand, need not impose any restriction on financing possibilities relative to the case of symmetric information about the state. The intuition for this is the following: if the two informed parties cannot collude with each other, it is possible to induce them to reveal their information truthfully, by providing incentives for one party to "call the other's bluff" if the other lies. More formally, we can rely on subgame perfect implementation to elicit information about $\gamma$ from the two informed parties without needing to increase their share of project income in equilibrium.

This effectively removes any potential moral hazard problem ex post, associated with the decision to continue or liquidate the project. Ex ante, on the other hand, the venture capitalist has to be given incentives to monitor, and the entrepreneur incentives to choose the "good" project. This entails pledging to them a sufficiently large share of the project's returns in the event of success, $R$. Intuitively, efficient provision of incentives also implies that their returns should be as low as possible when the project is liquidated (i.e. when the state $\gamma$ is "bad"); specifically, they should be equal to zero, because of limited liability.

We therefore obtain the following result.

Proposition 1. Assume that $\gamma$ is observed by the entrepreneur and the venture capitalist at $\mathrm{t}=1$ but not by outside investors, and that collusion is not feasible. Then:

(i) the entrepreneur can undertake the good project if, and only if, $A_{f} \geq A^{*}(\alpha)$, where $A^{*}(\alpha)$ is the critical threshold under symmetric information, and is given by $A^{*}(\alpha) \equiv C_{0}-L-p_{H}\left[\gamma_{G} R-C_{1}-L-\left(\left(b+c_{m}\right) / \Delta p\right)\right]-c_{m} p_{L} / \alpha^{2} \Delta p$;

(ii) optimal contracts, which allow the project to be financed whenever $A_{f} \geq$ $A^{*}(\alpha)$, have the following properties: (a) the equilibrium payoffs of the entrepreneur and the venture capitalist in the event of liquidation are equal to zero; and (b) information about $\gamma$ is obtained from the venture capitalist and the entrepreneur at $\mathrm{t}=1$ through a sequential mechanism which requires their agreement for the project to be continued. 
The critical threshold for entrepreneurial capital, $A^{*}(\alpha)$, reflects the need to pledge part of the project's returns in case of success to the entrepreneur, for incentive reasons. This reduces the returns that can credibly be promised to outside investors, and hence the capital that they are willing to contribute towards funding the project. Of course, the venture capitalist can provide capital, but he will require the expected rate of return $\alpha$ on the capital he provides. As noted earlier, this will exceed the outside investors' required rate of return as long as venture capitalists' skills and capital are relatively scarce in the economy, implying some rents for venture capitalists. The need to provide these rents, as well as compensation for the monitoring $\operatorname{cost} c_{m}$, further reduces the amount of project income that can be pledged to investors. Thus higher values of $\alpha$ and/or $c_{m}$ increase the critical threshold $A^{*}(\alpha)$.

The second part of the Proposition shows that, in general, optimal contracts with asymmetric information between the informed "insiders" and the uninformed outside investors and no possibility of collusion are not consistent with the fact that venture capitalists typically hold convertible securities. These represent a claim on at least some of the proceeds in the event of liquidation, which is not consistent with Proposition 1(ii)(a). Moreover, the sequential mechanism required to elicit information about $\gamma$ cannot be interpreted as a convertible security.

The allocation of control rights over the liquidation decision that emerges in these optimal contracts does embody an important feature of observed venture capital contracts, namely the fact that the intermediary has the power to force liquidation. This is consistent with the widespread use of redemption rights, discussed in detail below. On the other hand, the optimal contracts described by Proposition 1 also require the entrepreneur to have the power to force liquidation. The empirical evidence on this is less clear-cut. The reason is that the entrepreneur would typically need to have control of the board to initiate a liquidation; moreover, he may need a voting majority to ensure that the decision is approved (see Smith (2001) and Kaplan and Strömberg (2003)). ${ }^{4}$ In their study of 213 venture capital investments, Kaplan and Strömberg (2003) found that entrepreneurs (founders) had the majority of the board seats in $14 \%$ of cases, and venture capitalists in $25 \%$ of cases. In the remainder of cases neither had control, implying an important role for other board members; however, these were individuals mutually agreed upon by the venture capitalists and the entrepreneurs (founders), suggesting that they could not be counted upon to side systematically with the

\footnotetext{
${ }^{4}$ Board rights and voting rights can differ in venture capital contracts through the use of explicit agreements on the election of directors (see Kaplan and Strömberg (2003)).
} 
latter. As for voting rights ${ }^{5}$, the same study revealed that entrepreneurs had a voting majority in at most $24 \%$ of all financings, the corresponding figure for venture capitalists being $53 \% .{ }^{6}$ This suggests that in many cases entrepreneurs do not have the power to force liquidation.

Some intuition for the results described by Proposition 1(ii) can be obtained by comparing them with those that would apply under symmetric information about the state $\gamma$. In this case too, ex ante incentives could be provided by pledging to the entrepreneur and to the intermediary a sufficiently large share of the project's success returns, and a zero share of any proceeds in the event of liquidation. Ex post efficiency, on the other hand, could be guaranteed simply by specifying in the contract the efficient continuation decision contingent on $\gamma$, since $\gamma$ would be contractable. However, when $\gamma$ is only observed by the entrepreneur and the venture capitalist, it is not directly contractable; the information has to be elicited from the two informed parties.

There is some tension between the need to elicit information about $\gamma$ and the allocation of cashflow rights that would be optimal under symmetric information. In particular, when the entrepreneur and the venture capitalist receive nothing in the event of liquidation (all the proceeds go to uninformed investors), they both always prefer continuation to liquidation, which might lead them to claim that the state is good even when in fact it is bad. This potential problem can be solved using a simple sequential mechanism, with the property that the entrepreneur and the venture capitalist share (sequentially) the control rights over the continuation decision; in particular, each party can force liquidation, so that continuation requires agreement. Notice though that this type of mechanism is not collusion-proof: in the bad state, the venture capitalist and the entrepreneur will have an incentive to collude to secure higher payoffs. This suggests that we need to investigate the implications of allowing for the possibility of collusion.

\footnotetext{
${ }^{5}$ The calculation of voting rights is complicated by the fact that some of these are contingent on subsequent management performance and stock vesting milestones or contingencies. Kaplan and Strömberg deal with this difficulty by calculating both a minimum and a maximum number of votes for the venture capitalists, depending on future contingencies, and the corresponding votes for the entrepreneurs.

${ }^{6}$ These figures refer to the minimum contingency case, which tends to overestimate the control rights of the entrepreneurs. In the maximum contingency case, venture capitalists have a voting majority in $69 \%$ of all financings, and entrepreneurs have a voting majority in only $12 \%$ of financings.
} 


\subsection{Collusion deterred through contract design}

It might be argued that we should just assume away the possibility of collusion a priori, as was done above. Why? One argument in favour of such an assumption might be that the entrepreneur is capital-constrained : where would he find the resources necessary to induce the venture capitalist to collude? This objection does not seem convincing, since the entrepreneur will typically be able to generate some private benefits for the venture capitalist, if he wishes, by using corporate resources (including ideas, knowledge and information). He may, for example, allow the venture capitalist to influence decisions concerning supplier contracts or the recruitment of key employees, in a way that benefits the venture capitalist. Indeed, there is plenty of empirical evidence showing that venture capitalists play a very active role in negotiating with suppliers, recruiting senior management, and providing entrepreneurs with access to consultants, investment bankers and lawyers (Gompers and Lerner (1999), Hellmann and Puri (2002), Kaplan and Strömberg (2003), and Sahlman (1990)). This kind of involvement by venture capitalists could, in principle, facilitate collusion with entrepreneurs.

A more persuasive argument might be that venture capitalists will not be willing to collude because they will be concerned about the possible damage to their reputation. There are two aspects to this argument. First, there is the possibility that investors might discover ex post that collusion has taken place. However, this is unlikely if sufficient care is taken in choosing the form of the "favours". A good example here, particularly in the case of high-technology start-ups, would be the sharing of valuable knowledge and information that the entrepreneur possesses and/or acquires in the early stages of the venture. Second, an intermediary who systematically colludes with entrepreneurs instead of monitoring the projects will build up, over time, a poorer track record for project success than an intermediary who never shirks on monitoring. This will obviously affect his reputation in the market and hence his ability to stay in business. While concern over such longterm reputational effects will undoubtedly play a role, it seems unlikely that it will provide, on its own, a sufficiently powerful deterrent to collusion at all times. Thus simply ruling out the possibility of collusion by assumption does not seem justified.

We now study instead how collusion can be deterred endogenously, through an appropriate design of financial contracts. Note first that collusion may occur at two different stages. The entrepreneur and the venture capitalist may collude ex ante, at $t=0$, so that the venture capitalist does not monitor, and the entrepreneur chooses the bad project yielding private benefits $B$. They may also collude 
ex post, at $t=1$, so as to induce continuation even in the bad state, which gives them strictly positive expected payoffs (unlike liquidation).

Ex-ante collusion would require some form of transfer (favour) from the entrepreneur to the venture capitalist, to induce the latter not to monitor. The simplest way to capture the different possible ways in which collusive transfers might occur is through a linear collusion technology: that is, by assuming that a transfer which costs $S$ to the giver benefits the receiver by an amount $k S$. We assume that $1 \geq k>0$ : the case where $k<1$ implies the existence of transactions costs of collusion, including, for example, the effect of reputational concerns as discussed above, which would tend to reduce the benefit to the receiver. In principle, the case where $k>1$ cannot be ruled out: for example, the entrepreneur might possess some private information that is potentially more valuable to the venture capitalist than to himself. For simplicity, we focus attention on what we consider to be the most plausible case, $1 \geq k>0$. As for ex-post collusion, this could occur even in the absence of any collusive transfers. The reason is that when the entrepreneur and the venture capitalist do not receive any of the proceeds in the event of liquidation, both parties stand to gain from continuing the project in the bad state, and can agree to coordinate on this outcome without any need for favours.

The following result summarises the main implications of the need to deter collusion through the design of venture capital contracts.

Proposition 2. Assume $\gamma$ is observed by the entrepreneur and the venture capitalist at $\mathrm{t}=1$, but not by outside investors. Then:

(i) allowing for the possibility of collusion raises the minimum amount of entrepreneurial capital required to undertake the good project to:

$$
A_{C}^{*}(\alpha) \equiv A^{*}(\alpha)+p_{H} k(B-b)\left[1-\left(1 / \alpha^{2}\right)\right] / \Delta p+\gamma_{B}(c+k B)\left[1-\left(1 / \alpha^{2}\right)\right] / \Delta p \Delta \gamma,
$$
where $A^{*}(\alpha)$ is the critical threshold when collusion is not feasible, given in Proposition 1 ;

(ii) optimal collusion-proof contracts, which allow the good project to be financed whenever $A_{f} \geq A_{C}^{*}(\alpha)$, have the following properties: (a) the venture capitalist is given control rights over the decision to continue or liquidate the project at $\mathrm{t}=1$; and (b) the allocation of cashflow rights provides the venture capitalist with incentives to take the efficient continuation/liquidation decision; this entails giving him a share of the proceeds in the event of liquidation.

Financing constraints are clearly exacerbated by the need to deter collusion. This is because there are essentially two ways of deterring collusion: making 
it less attractive to the entrepreneur, which requires increasing his share of the project's expected income, or making it less attractive to the venture capitalist, which requires giving him a greater share of the project's expected income instead. When the entrepreneur is sufficiently capital-constrained, the first option is not feasible, as the entrepreneur cannot increase his capital contribution to make up for the shortfall. The venture capitalist, on the other hand, can provide additional capital to "pay" for his higher expected income from the project, but he will also extract some rents $(\alpha>1)$ : this makes the financing constraint tighter (i.e. it increases $\left.A_{C}^{*}(\alpha)\right)$.

Proposition 2(ii) shows that optimal collusion-proof contracts are consistent with commonly observed characteristics of venture capital contracts. First, the venture capitalist is given control rights over the continuation decision. In particular, he is given both the right and the incentives to liquidate the project in the bad state. The intuition for this is as follows. The possibility of collusion means that we can no longer implement the optimal continuation/liquidation decision while reducing the two informed parties' equilibrium payoffs in the bad state to zero by giving one party the incentive to "call the other's bluff" as the parties would collude to secure higher payoffs. The optimal continuation decision can only be implemented (and collusion deterred) by increasing the entrepreneur's and/or the venture capitalist's equilibrium payoffs in the event of liquidation. To minimise the need for entrepreneurial capital, we rely on the second option. This implies giving the venture capitalist the power and the incentives to liquidate the project in the bad state. This is consistent with the use of redemption rights ${ }^{7}$ in venture capital contracts: as Gompers (1997) notes, these rights imply that "essentially, the venture capitalists can force the firm to repay the face value of the investment at any time. This mechanism can often be used to force liquidation". 8

Second, the allocation of cashflow rights is also consistent with common prac-

\footnotetext{
${ }^{7}$ Venture capitalists' redemption rights can take one of two forms: mandatory redemption rights and optional investor redemption ("put") rights. Mandatory redemption requires the company to begin repurchasing shares at a specified date, usually subject to waiver by the venture capitalists. Optional investor redemption rights, which are much more common, allow venture capitalists to force the repurchase of their shares at their discretion. They can typically be exercised after a given date.

${ }^{8}$ With both types of redemption right, the venture capitalist essentially acquires liquidation rights from a given date onwards. Earlier in the venture capital relationship, the venture capitalist effectively controls the continuation / liquidation decision through the use of staged financing and negative covenants. For a more detailed discussion, see Smith (2001) and Kaplan and Strömberg (2003).
} 
tice in venture capital finance, where convertible securities (convertible preferred equity and convertible debt) are the most commonly used financial instruments ${ }^{9}$. In particular, under plausible assumptions, the venture capitalist's payoffs can be interpreted as the payoffs to a convertible security: a debt claim with face value equal to his share of liquidation proceeds and an option to convert this to an equity share which will have the appropriate value at $t=2$ if the project succeeds. The values of the debt claim and the equity share are chosen so that the venture capitalist has an incentive to continue the project and exercise the conversion option in the good state, while in the bad state he will prefer to liquidate without exercising the conversion option.

One implication of this interpretation is that the intermediary's decision to continue and exercise the conversion option can act as a credible signal to uninformed investors that the firm's prospects are good: this too seems consistent with the empirical evidence on venture capital financing. Continuation finance is often raised through IPOs, and venture capitalists are required to exercise their conversion option at this point. Megginson and Weiss (1991), in their study of 320 venture-backed and 320 nonventure IPOs over the period 1983-87, find that venture capitalists retain a majority of their equity after the IPO, and that the underpricing of venture-backed IPOs is significantly less than the underpricing of nonventure IPOs. They interpret this as evidence that venture capitalists certify to investors the quality of the firms they bring to market. Their argument for this certification hypothesis is based on reputational considerations: the idea is that venture capitalists have an incentive to build a reputation for bringing highquality firms to market, which in turn will reduce the costs of taking firms public in the future. The results described above suggest that venture capitalists' certification role does not rely only on reputation, but also on the design of financial contracts, which provides the appropriate incentives for certification.

Finally, note that while the optimal collusion-proof contract can be imple-

\footnotetext{
${ }^{9}$ Convertible securities are the most commonly held securities by venture capitalists in the US (see Gompers and Lerner (1999), Kaplan and Strömberg (2003)). Outside the US, a variety of securities are used, notably in Canada (where common equity dominates), Europe, and in developing countries. On this see Cumming (2005a, 2005b, 2006), Cumming et al. (2009), Hege et al. (2003), Kaplan et al. (2003), Lerner and Schoar (2005) and Schwienbacher (2002). Interestingly, Cumming (2005a), using Canadian data, finds that high-tech firms are more likely to be financed with convertible preferred equity than other firms. High-tech firms, as discussed earlier, may be particularly vulnerable to potential collusion problems; moreover, in view of the high risks involved, the need to induce the efficient decision between continuation and liquidation would seem to be especially important.
} 
mented with convertible securities or a combination of debt and equity, it cannot, in general, be implemented with straight debt or straight equity : this may provide an explanation for the difference between the financial claims typically held by venture capitalists (convertible securities), and those held by business angels for whom the possibility of collusion is not an issue (straight equity). ${ }^{10}$

\section{Advising}

This section examines the case where venture capitalists provide advice (e.g. strategic advice, customer introductions) but do not monitor (intervene). This case has been studied, in different settings, in a number of contributions, including Bottazzi et al. (2005), Casamatta (2003), Cestone (2000), Hellmann (1998), Kaplan et al. (2003), Lerner and Schoar (2005), Repullo and Suarez (2000, 2004), and Schmidt (2003). The main novelty here is is the analysis of how the possibility of collusion shapes optimal financial contracts between entrepreneurs and financiers/advisers. As in the previous section, I begin by assuming that collusion is never feasible. I will then relax this assumption and investigate the optimal design of contracts that deter collusion. I focus throughout on the more interesting case where $\alpha$ is not too large, so that it is indeed in the entrepreneur's interest to obtain the venture capitalist's advice.

\subsection{Collusion ruled out a priori}

If collusion is not feasible, we can once again design contracts that will elicit information about the realised state $\gamma$ from the entrepreneur and the venture capitalist at $t=1$, at no additional cost relative to the case where the state is publicly observable and contractable. As in the monitoring case studied in the previous section, this removes any potential moral hazard problem associated with the decision to continue or liquidate the project. The venture capital contract then needs to provide appropriate incentives ex ante: it needs to motivate the venture capitalist to advise, and the entrepreneur to choose the good project. This yields a very similar result to the one described by Proposition 1:

Proposition 3. Assume that $\gamma$ is observed by the entrepreneur and the venture capitalist at $\mathrm{t}=1$ but not by outside investors, and that collusion is not feasible.

\footnotetext{
${ }^{10}$ See Fenn, Liang and Prowse (1998) on business angels and Gompers and Lerner (1999) and Kaplan and Strömberg (2003) on venture capitalists.
} 
Then:

(i) the entrepreneur can undertake the good project if, and only if, $A_{f} \geq$ $A^{* *}(\alpha)$, where $A^{* *}(\alpha)$ is the critical threshold under symmetric information, and is given by

$A^{* *}(\alpha)=C_{0}-L-\left(p_{H}+q\right)\left[\gamma_{G} R-C_{1}-L-B / \Delta p-c_{a} / q\right]-c_{a} p_{H} / \alpha^{2} q ;$

(ii) optimal contracts, which allow the project to be financed whenever $A_{f} \geq$ $A^{* *}(\alpha)$, have the following properties: (a) the equilibrium payoffs of the entrepreneur and the venture capitalist in the event of liquidation are equal to zero; and (b) information about $\gamma$ is obtained from the venture capitalist and the entrepreneur at $t=1$ through a sequential mechanism which requires their agreement for the project to be continued.

Intuitively, when collusion is ruled out exogenously, the main difference between advice and monitoring is simply that advice increases the project's Net Present Value (NPV), while monitoring decreases NPV but is nevertheless valuable because it relaxes financing constraints by reducing the share of expected income that needs to be pledged to the entrepreneur for incentive reasons, hence increasing pledgeable income.

\subsection{Collusion deterred through contract design}

Once we allow for the possibility of collusion, a further difference emerges between advising and monitoring. If the venture capitalist's role is to provide financing and advice, but no monitoring, there is no scope for ex ante collusion between the entrepreneur and the venture capitalist. There remains, on the other hand, scope for collusion ex post. The reason is that the optimal contracts described by Proposition 3 entail a payoff of value zero in the event of liquidation for both the entrepreneur and the venture capitalist, while continuation would give them positive expected payoffs. It is therefore in their interest to collude to ensure that the project is continued even when the realised state $\gamma$ is bad.

Taking this into account, we obtain the following result.

Proposition 4. Assume $\gamma$ is observed by the entrepreneur and the venture capitalist at $\mathrm{t}=1$, but not by outside investors. Then:

(i) the minimum amount of entrepreneurial capital required to undertake the good project once we allow for the possibility of collusion is given by:

$A_{C}^{* *}(\alpha)=C_{0}-L-\left(p_{H}+q\right)\left(\gamma_{G} R-L-B / \Delta p\right)+c_{a} / \alpha^{2}+\left(1-1 / \alpha^{2}\right) k \gamma_{B} B / \Delta p \Delta \gamma+$ $\left(1-1 / \alpha^{2}\right) \pi c_{a} / q \Delta \gamma$; 
(ii) optimal collusion-proof contracts, which allow the good project to be financed whenever $A_{f} \geq A_{C}^{* *}(\alpha)$, have the following properties: (a) the venture capitalist is given control rights over the decision to continue or liquidate the project at $\mathrm{t}=1$; and (b) the allocation of cashflow rights provides the venture capitalist with incentives to take the efficient continuation/liquidation decision; this entails giving him a share of the proceeds in the event of liquidation.

Clearly, the key result concerning the allocation of control rights and cashflow rights that was obtained for the monitoring case also applies when the venture capitalist provides advice rather than monitoring. In particular, the venture capitalist is given control rights over the decision to continue or liquidate the project, and cashflow rights that provide the right incentives for him to exercise those control rights efficiently. Once again, these cashflow rights can be interpreted as payoffs to a convertible security. As discussed earlier in detail, these characteristics are consistent with observed practice in the venture capital industry. The results of this section show that they emerge as part of optimal collusion-proof contracts not only when venture capitalists act as monitors, as in Dessi (2005), but also when they act as advisers, as in a number of other recent contributions to the literature.

\section{Conclusions}

In this chapter, I have explored some of the implications of venture capitalists' roles as financiers, monitors and advisors. I have done this using a simple, unified theoretical framework, which brings out the connections and differences between monitoring and advising. The results show that some of the key findings on the optimal allocation of control rights and cashflow rights in Dessi (2005), which focused exclusively on venture capitalists' role as monitors, also apply when we consider instead their role as providers of advice and support. Of course, there are many aspects of venture capitalists' roles that are not captured here. For example, their role in replacing founders with outside CEOs is not studied here: Hellmann (1998) provides an excellent analysis. The provision of advice and support has also been studied in a variety of settings, as noted at the beginning of section 4 : the contributions cited there provide many additional insights. One issue that has received relatively less attention in the theoretical literature is the joint allocation of control rights and cashflow rights. Some important exceptions include Cestone (2000) and Hellmann (2000). Cestone focuses on the potential trade-off between 
the need to encourage entrepreneurial initiative in the early stages of a venture and the need to elicit the venture capitalist's support (help and advice) in later stages. Hellmann examines the optimal allocation of cashflow rights and control rights between entrepreneurs and venture capitalists when there is ex-ante uncertainty as to whether exit should eventually occur through an acquisition or an IPO. In view of the diversity, richness and complexity of venture capital financings (see, among others, Bottazzi and Da Rin (2002), Gompers and Lerner (1999), Kaplan and Stromberg $(2003,2004))$, there remains nevertheless plenty of scope for further research on these issues. 


\section{Appendix}

Proofs of Propositions 1 and 2. See Dessi (2005).

Proof of Proposition 3.

Denote by $C 3=\left\{A_{f}, A_{u}, A_{m}, \Psi, L_{f}, L_{u}, L_{m}, R_{f}, R_{u}, R_{m}\right\}$ the contract proposed by the entrepreneur to the venture capitalist and the uninformed investors at $t=0$. The subscript $f$ refers to the entrepreneur, $u$ to the uninformed investors, and $m$ to the venture capitalist. The first three terms represent each party's initial capital contribution to the project; the next term denotes the mechanism that will be played by the entrepreneur and the venture capitalist at $t=1$ to elicit information about the state $\gamma$ and implement the efficient continuation/liquidation decision; the following three terms represent each party's payoff in the event of liquidation; the last three terms denote the payoffs if the project is continued and succeeds.

The proof proceeds as follows: I first characterise the contract that would make it possible to finance the good project with the lowest possible level of entrepreneurial capital in the presence of symmetric information; i.e. if the contract could simply specify that at $t=1$ the project will be continued when $\gamma=\gamma_{G}$ and liquidated otherwise. I will then give an example of a mechanism that makes it possible to implement the same decision rule for project continuation/liquidation without imposing any additional restriction, thereby completing the proof.

In the presence of symmetric information as just described, we can specify the entrepreneur's problem $(P 3)$ as follows:

$$
\begin{gathered}
\operatorname{Max} \quad\left(p_{H}+q\right) \gamma_{G} R_{f}+\left(1-p_{H}-q\right) L_{f}-A_{f} \\
\text { s.t. } \quad\left(p_{H}+q\right) \gamma_{G} R_{f}+\left(1-p_{H}-q\right) L_{f} \geq B+\left(p_{L}+q\right) \gamma_{G} R_{f}+\left(1-p_{L}-q\right) L_{f} \\
R_{f}+R_{u}+R_{m}=R \\
L_{f}+L_{u}+L_{m}=L \\
A_{f}+A_{u}+A_{m}=C_{0}
\end{gathered}
$$




$$
\begin{gathered}
\left(p_{H}+q\right)\left(\gamma_{G} R_{u}-C_{1}\right)+\left(1-p_{H}-q\right) L_{u} \geq A_{u} \\
\left(p_{H}+q\right) \gamma_{G} R_{m}+\left(1-p_{H}-q\right) L_{m} \geq c_{a}+p_{H} \gamma_{G} R_{m}+\left(1-p_{H}\right) L_{m} \\
\left(p_{H}+q\right) \gamma_{G} R_{m}+\left(1-p_{H}-q\right) L_{m}-c_{a} \geq \alpha^{2} A_{m}
\end{gathered}
$$

Expression (6.1) represents the entrepreneur's expected payoff, while his incentive compatibility constraint is given by (6.2). Expressions (6.3) to (6.5) are feasibility constraints, and (6.6) is the investors' participation constraint. The venture capitalist's incentive compatibility and participation constraints are given by (6.7) and (6.8), respectively.

The method of proof is the following: first, obtain lower bounds for $R_{f}, R_{m}, L_{f}$ and $L_{m}$, using the entrepreneur's and the venture capitalist's ICCs, together with limited liability. Second, using these lower bounds together with the participation constraints, derive the minimum amount of entrepreneurial capital required for the project to be undertaken. Notice that, since $\alpha^{2} \geq 1$, we can focus without loss of generality on the case where the intermediary's capital investment, $A_{m}$, is just equal to the minimum amount necessary to satisfy his participation and incentive compatibility constraints; any additional external finance is raised directly from investors.

From the entrepreneur's ICC, together with limited liability, we have:

$$
\begin{gathered}
R_{f} \geq B / \Delta p \gamma_{G}+L_{f} / \gamma_{G} \\
L_{f} \geq 0
\end{gathered}
$$

and from the venture capitalist's ICC, together with limited liability, we have:

$$
\begin{gathered}
R_{m} \geq c_{a} / q \gamma_{G}+L_{m} / \gamma_{G} \\
L_{m} \geq 0
\end{gathered}
$$

Using the lower bounds implied by (6.11) and (6.12), and the venture capitalist's participation constraint, we obtain: 


$$
A_{m}=c_{a} p_{H} / \alpha^{2} q
$$

Using conditions (6.9) to (6.12), together with the feasibility constraints (6.3) and (6.4), gives the following upper bounds for $R_{u}$ and $L_{u}$ :

$$
\begin{gathered}
R_{u}^{\max }=R-B / \Delta p \gamma_{G}-c_{a} / q \gamma_{G} \\
L_{u}^{\max }=L
\end{gathered}
$$

Hence the maximum amount of capital that can be raised from investors is obtained from their participation constraint:

$$
A_{u}^{\max }=L+\left(p_{H}+q\right)\left[\gamma_{G} R-C_{1}-L-B / \Delta p-c_{a} / q\right]
$$

Expressions (6.5), (6.13) and (6.16) together imply that the project can only be financed if the entrepreneur's capital satisfies the following condition:

$$
A_{f} \geq A^{* *}(\alpha)=C_{0}-L-\left(p_{H}+q\right)\left[\gamma_{G} R-C_{1}-L-B / \Delta p-c_{a} / q\right]-c_{a} p_{H} / \alpha^{2} q
$$

When the above condition is satisfied, it can be easily checked that the following is a solution to P3: let $A_{f}=A^{* *}, A_{m}=c_{a} p_{H} / \alpha^{2} q, A_{u}=C_{0}-A_{f}-A_{m}, L_{f}=0$, $L_{m}=0, L_{u}=L, R_{f}=B / \Delta p \gamma_{G}, R_{m}=c_{a} / q \gamma_{G}, R_{u}=R-R_{f}-R_{m}$.

Now consider the following mechanism $\Psi$ :

- Stage 1: the venture capitalist chooses between continuation and liquidation. If he chooses liquidation, the project is liquidated; payoffs are $L_{f}, L_{u}$, and $L_{m}$. If the venture capitalist chooses continuation, go on to stage 2 .

- Stage 2: the entrepreneur decides whether to agree with the venture capitalist or disagree. If he agrees, the project is continued, investors provide the required finance $C_{1}$, and payoffs are $R_{f}, R_{u}$, and $R_{m}$ if the project succeeds; zero otherwise. If the entrepreneur disagrees, the project is liquidated; the entrepreneur receives $\gamma_{B} R_{f}+\epsilon$, the investors any remaining liquidation proceeds, and the venture capitalist zero.

For $\Psi$ to work, it has to satisfy the following conditions: 


$$
\begin{gathered}
\gamma_{G} R_{f} \geq \gamma_{B} R_{f}+\epsilon \\
\gamma_{B} R_{f}+\epsilon \geq \gamma_{B} R_{f} \\
L_{m} \geq 0 \\
\gamma_{G} R_{m} \geq L_{m}
\end{gathered}
$$

The first two conditions ensure that in stage 2 the entrepreneur agrees if $\gamma=$ $\gamma_{G}$, and disagrees if $\gamma=\gamma_{B}$. The last two conditions ensure that in stage 1 the intermediary prefers to liquidate if $\gamma=\gamma_{B}$ and to continue if $\gamma=\gamma_{G}$. Clearly $\epsilon$ can always be chosen to satisfy the first two conditions. Comparing the last two conditions with those for problem $P 3$, given above, shows that they impose no additional restriction: it is therefore possible to implement the lower bounds for $R_{f}, R_{m}, L_{f}$, and $L_{m}$ obtained earlier. Thus the minimum level of entrepreneurial capital required for the project to be feasible satisfies the condition:

$$
A_{f} \geq A^{* *}(\alpha)
$$

as in the case of symmetric information.

Proof of Proposition 4.

The entrepreneur at $t=0$ proposes a contract $C 4=\left\{A_{f}, A_{u}, A_{m}, \Psi, L_{f}\right.$, $\left.L_{u}, L_{m}, R_{f}, R_{u}, R_{m}\right\}$ to the venture capitalist and the uninformed investors. The difference with contract $C 3$ in Proposition 3 is that the contract needs to be collusion-proof. Once we allow for the possibility of collusion, the entrepreneur and the venture capitalist can always agree to make the same announcements when $\gamma=\gamma_{B}$ as when $\gamma=\gamma_{G}$, giving the outcome \{continuation, success payoffs $\left.R_{f}, R_{m}\right\}$ with expected payoffs equal to $\gamma_{B} R_{f}, \gamma_{B} R_{m}$. Thus it is no longer possible to implement the equilibrium payoffs that were optimal when collusion was ruled out a priori. To implement the optimal continuation/liquidation decision while minimising the returns pledged to the entrepreneur (hence minimising the need for entrepreneurial capital), we must have:

$$
L_{f}=0
$$


and set $L_{m}$ so that the venture capitalist prefers liquidation to continuation when $\gamma=\gamma_{B}$ (in particular, so that he cannot be induced to collude with the entrepreneur to choose continuation):

$$
L_{m} \geq \gamma_{B} R_{m}+k \gamma_{B} R_{f}
$$

The venture capitalist's ex ante ICC (see below) requires that he prefer continuation when $\gamma=\gamma_{G}$ (otherwise he has no incentives to advise). Without loss of generality we can therefore specify the mechanism $\Psi$ as follows:

- at $t=1$ the venture capitalist decides whether to continue the project or liquidate it. If the project is liquidated, the entrepreneur receives $L_{f}=0$, the venture capitalist $L_{m}=\gamma_{B} R_{m}+k \gamma_{B} R_{f}$, and the investors any remaining liquidation proceeds. If the project is continued, investors provide the required finance $C_{1}$, and payoffs are given by $R_{f}, R_{u}, R_{m}(0)$ in the event of success (failure).

The venture capitalist's ex ante ICC is given by

$$
\left(p_{H}+q\right) \gamma_{G} R_{m}+\left(1-p_{H}-q\right) L_{m} \geq c_{a}+p_{H} \gamma_{G} R_{m}+\left(1-p_{H}\right) L_{m}
$$

The lower bounds for $R_{f}$ and $L_{f}$ are the same as in Proposition 3, and are given by (6.9) and (6.10), implying that the lower bound for $R_{m}$ is given by (6.11); substituting for $L_{m}$ using (6.24) gives the following condition:

$$
R_{m} \geq c_{a} / q \Delta \gamma+\gamma_{B} k B / \gamma_{G} \Delta p \Delta \gamma
$$

Let $R_{m}^{\min }=c_{a} / q \Delta \gamma+\gamma_{B} k B / \gamma_{G} \Delta p \Delta \gamma$. Then the amount of capital provided by the venture capitalist is equal to:

$A_{m}=\left[\left(p_{H}+q\right) \gamma_{G}+\left(1-p_{H}-q\right) \gamma_{B}\right] R_{m}^{\min } / \alpha^{2}+\left(1-p_{H}-q\right) k \gamma_{B} B / \alpha^{2} \Delta p \gamma_{G}-c_{a} / \alpha^{2}$

Further manipulation shows that the project can be financed if and only if $A_{f} \geq$ $A_{C}^{* *}(\alpha)$, where

$$
\begin{aligned}
& A_{C}^{* *}(\alpha)=C_{0}-L-\left(p_{H}+q\right)\left(\gamma_{G} R-L-B / \Delta p\right)+c_{a} / \alpha^{2}+\left(1-1 / \alpha^{2}\right) k \gamma_{B} B / \Delta p \Delta \gamma+\left(1-1 / \alpha^{2}\right) \pi c_{a} / q \Delta \gamma \\
& \quad \text { and } \pi \equiv\left(p_{H}+q\right) \gamma_{G}+\left(1-p_{H}-q\right) \gamma_{B} .
\end{aligned}
$$




\section{References}

Admati, A.R. and Pfleiderer, P. "Robust Financial Contracting and the Role of Venture Capitalists." Journal of Finance, Vol. 49 (1994), pp. 371-402.

Barclay, M.J. and Holderness, C.G. "Private Benefits from Control of Public Corporations." Journal of Financial Economics, Vol. 25 (1989), pp. 371-395.

Bergemann, D. and Hege, U. "Venture Capital Financing, Moral Hazard, and Learning." Journal of Banking and Finance, Vol. 22 (1998), pp. 703-735.

Berglof, E. "A Control Theory of Venture Capital Finance." Journal of Law, Economics and Organisation, Vol. 10 (1994), pp. 247-267.

Bergstrom, C. and Rydqvist, K. "Ownership of Equity in Dual-class Firms." Journal of Banking and Finance, Vol. 14 (1990), pp. 255-269.

Bottazzi, L. and Da Rin, M. (2002) "Venture Capital in Europe and the Financing of Innovative Companies", Economic Policy, 17(34), 231-269.

Bottazzi, L., Da Rin, M., and T. Hellmann (2005) "What Role of Legal Systems in Financial Intermediation? Theory and Evidence", mimeo, Università Bocconi.

Brickley, J.A., Lease, R.C. and Smith JR., C.W. "Ownership Structure and Voting on Antitakeover Amendments." Journal of Financial Economics, Vol. 20 (1988), pp. 267-291.

Casamatta, C. "Financing and Advising: Optimal Financial Contracts with Venture Capitalists." Journal of Finance, Vol. 58 (2003), pp. 2059-2085.

Cestone, G. "Venture Capital Meets Contract Theory : Risky Claims or Formal Control?." Mimeo, Institut d'Analisi Economica, Barcelona, 2000.

Cornelli, F. and Yosha, O. "Stage Financing and the Role of Convertible Debt." Review of Economic Studies, Vol. 70 (2003), pp. 1-32.

Cumming, D.J. (2005a) "Agency Costs, Institutions, Learning and Taxation in Venture Capital Contracting", Journal of Business Venturing, 20, 573-622.

Cumming, D.J. (2005b) "Capital Structure in Venture Finance", Journal of Corporate Finance, 11, 550-585.

Cumming, D.J. (2006) "Adverse Selection and Capital Structure: Evidence from Venture Capital", Entrepreneurship Theory and Practice, 30, 155-184.

Cumming, D.J., D. Schmidt and U. Walz (2009) "Legality and Venture Capital Governance around the World", Journal of Business Venturing, forthcoming.

de Bettignies, J.-E. (2008) "Financing the Entrepreneurial Venture", Management Science, 54(1), 151-166.

Dessí, R. (2005) "Start-up Finance, Monitoring, and Collusion", Rand Journal 
of Economics, 36(2), 255-274.

Dessí, R. (2008) "Contractual Execution and Strategic Incompleteness", IDEI Working Paper, Toulouse School of Economics.

Diamond, D. "Financial Intermediation and Delegated Monitoring." Review of Economic Studies, Vol. 51 (1984), pp. 393-414.

Felli, L. "Collusion in Incentive Contracts: Does Delegation Help?." Mimeo, MIT, 1990.

Fenn, G., Liang, N. and Prowse, S. "The Role of Angel Investors in Financing High-tech Start-ups." Mimeo, CEPR, 1998.

Freixas, X. and Rochet, J.C. Microeconomics of Banking, MIT Press, 1997.

Gompers, P. "Ownership and Control in Entrepreneurial Firms: An Examination of Convertible Securities in Venture Capital Investments." Mimeo, Harvard and NBER, 1997.

Gompers, P. and Lerner, J. The Venture Capital Cycle, The MIT Press, 1999.

Gorman, P. and Sahlman, W. "What Do Venture Capitalists Do?." Journal of Business Venturing, Vol. 4 (1989), pp. 231-248.

Hege, U., F. Palomino and A. Schwienbacher (2003) "Determinants of venture capital performance: Europe and the United States", Working Paper.

Hellmann, T. "The Allocation of Control Rights in Venture Capital Contracts." Rand Journal of Economics, Vol. 29 (1998), pp. 57-76.

Hellmann, T. "IPOs, Acquisitions and the Use of Convertible Securities in Venture Capital." Research Paper No. 1702, Stanford Graduate School of Business, 2000.

Hellmann, T. and Puri, M. "Venture Capital and the Professionalization of Start-up Firms : Empirical Evidence." Journal of Finance, Vol. 57 (2002), pp. $169-197$.

Holmstrom, B. and Tirole, J. "Financial Intermediation, Loanable Funds, and the Real Sector." Quarterly Journal of Economics, Vol. CXII (1997), pp. 663-691.

Kaplan, S.N., Martel, F., and Stromberg, P. (2003) "How Do Legal Differences and Learning Affect Financial Contracts?", mimeo, University of Chicago.

Kaplan, S.N. and Stromberg, P. "Financial Contracting Theory Meets the Real World: An Empirical Analysis of Venture Capital Contracts." Review of Economic Studies, Vol. 70 (2003), pp. 281-315.

Kaplan, S.N. and P. Strömberg (2004) "Characteristics, contracts, and actions: evidence from venture capitalist analyses", Journal of Finance, 59, 2177-2210.

Laffont, J.J. and Rochet, J.C. (1997) "Collusion in Organizations." Scandinavian Journal of Economics, Vol. 99 (1997), pp. 485-495. 
Lerner, J. (1995) "Venture Capitalists and the Oversight of Private Firms", Journal of Finance, 50, 301-318.

Lerner, J. and Schoar, A. (2005) "Does Legal Enforcement Affect Financial Transactions? The Contractual Channel in Private Equity", Quarterly Journal of Economics, 120, 223-246.

Maug, E. "Insider Trading Legislation and Corporate Governance." European Economic Review, Vol. 46 (2002), pp. 1569-1597.

Megginson, W.L. and Weiss, K.A. "Venture Capitalist Certification in Initial Public Offerings." Journal of Finance, Vol. 46 (1991), pp. 879-903.

Moore, J. "Implementation in Environments with Complete Information." in Advances in Economic Theory, ed. J.J. Laffont, Cambridge University Press, 1992.

Moore, J. and Repullo,R. "Subgame Perfect Implementation." Econometrica, Vol. 56 (1988), pp. 1191-1220.

Pagano, M. and Roell,A. "The Choice of Stock Ownership Structure: Agency Costs, Monitoring, and the Decision to Go Public." Quarterly Journal of Economics, Vol. 113 (1998), pp. 1985-2225.

Pound, J. "Proxy Contests and the Efficiency of Shareholder Oversight." Journal of Financial Economics, Vol. 20 (1988), pp. 237-265.

Rajan, R. "Insiders and Outsiders: The Choice Between Informed and Arm's Length Debt." Journal of Finance, Vol. 47 (1992), pp. 1367-400.

Repullo, R. and Suarez, J. (2000) "Entrepreneurial Moral Hazard and Bank Monitoring: A Model of the Credit Channel", European Economic Review, 44, 1931-1950.

Repullo, R. and Suarez, J. (2004) "Venture Capital Finance: A Security Design Approach", Review of Finance, 8, 75-108.

Sahlman, W. "The Structure and Governance of Venture-capital Organizations." Journal of Financial Economics, Vol. 27 (1990), pp. 473-521.

Schmidt, K. "Convertible Securities and Venture Capital Finance." Journal of Finance, Vol. 58 (2003), pp. 1139-1166.

Schwienbacher, A. (2002) "Venture capital exits in Europe and the United States", Working Paper, University of Amsterdam.

Shleifer, A. and Vishny, R.W. "Large Shareholders and Corporate Control." Journal of Political Economy, Vol. 94 (1986), pp. 461-488.

Smith, D.G. "Control Over Exit in Venture Capital Relationships." paper presented at the EFMA Meeting in Lugano, Switzerland, 2001.

Tirole, J. "Hierarchies and Bureaucracies: On the Role of Collusion in Or- 
ganizations." Journal of Law, Economics and Organization, Vol. 2 (1986), pp. 181-214.

Tirole, J. "Collusion and the Theory of Organizations." in Advances in Economic Theory, vol. 2, ed. J.J. Laffont, Cambridge University Press, 1992.

Zingales, L. "The Value of the Voting Right: A Study of the Milan Stock Exchange Experience." Review of Financial Studies, Vol. 7 (1994), pp. 125-148. 